\title{
"Natural Chronometers": Coral Islands and the Discovery of Time, from Buffon to Darwin
}

\author{
Richard Lansdown
}

James Cook University

\begin{abstract}
Two phenomena in particular offered hints to early nineteenth-century geology about dating the antiquity of the earth: volcanos of the kind discovered at Pompeii, and coral rock of the kind discovered, above all, in the tropical Pacific. This paper surveys the growth in knowledge of coral between the theories offered up by Johann Reinhold Forster (who accompanied James Cook on his second voyage of 1772-1775) to those more or less authoritative ones published by Charles Darwin in his Structure and Distribution of Coral Reefs of 1842. Inputs both religious and secular are included, because the Biblical element imaginatively accompanied, and sometimes stimulated, the more strictly empirical endeavours of scientists. What was needed for nineteenth-century geological and biological theories to gain a footing was a new vision of time, and coral was a 'natural chronometer' of momentous importance in demonstrating how old the earth must be.
\end{abstract}

$\mathrm{T}$ he "first branch of natural science to become genuinely historical," Stephen Toulmin and June Goodfield wrote in The Discovery of Time (141), "was geology." In the early nineteenth century, between the era of Cuvier and that of Darwin, biology arose to accompany geology, and, as Toulmin and Goodfield went on (143), "the intellectual claims of the modern, extended time-scale were finally established by the resultant interweaving of geological considerations with evolutionary ones."

Another doyen of the history of geology, Martin Rudwick, reminds us of two key features of that discovery - or two misunderstandings of it, to be precise. First: that "religious and scientific practices and knowledge interacted" during the interweaving Toulmin and Goodfield describe. "Rather than being the enemy of progress in the sciences of the earth," Christianity in fact "fostered the extension of historicity to the previously uncharted vastnesses of pre-human time," as a product and a result of its own fascination with Biblical history, Biblical origins, and Biblical accounts of the creation (Rudwick, Bursting the Limits of Time 6, 643; my italics). Second: that "it was...the human imagination that needed to be stretched, even among savants, before talk of vast amounts of time could begin to seem anything more than vacuous and scientifically irresponsible hand-waving" (Rudwick, Bursting the Limits of Time 1245; my italics). "Something more than outcrops of well-hammered rocks and trays of well-handled fossil specimens was needed," Rudwick argues elsewhere, "before any pictorial sense of the world at the time of their formation became-in the literal sense-conceivable." Rudwick has illustrators in mind here, but writers, too, were in the business of building what he calls "human constructions: not unconstrained by the natural evidence available at a given period, but certainly using that evidence in a 
representation that has many other inputs besides the fossil bones and shells themselves" (Scenes from Deep Time 227, 223). Both religious people and imaginative people played their roles in the discovery of time, and the particular focus of their attention I want to discuss here is coral: a zoological interweaver whose biological activity has a posthumous geological result.

Without rehearsing the debate between the "Vulcanists" (for whom volcanic forces were the chief engine of geological change) and the 'Nepunists' (for whom changes in sea level performed the same role), it is clear that the sea played a massive role in the confluence of geology and biology Toulmin and Goodfield describe, in both religious and imaginative terms. "Evidence" for changes in sea level, after all, was writ large in the Biblical account of the deluge: in discussing which a student of geology and a student of the Old Testament could be the same person. On the other hand, the sea in the late eighteenth century was an element that empirical observation could hardly penetrate at all. Objects could be dropped into it and hauled back up again; a person could dive a few fathoms with his eyes open; creatures of all sorts came up in fishermen's nets; but there was no way the ocean could systematically be explored beneath its surface: so the imagination had a peculiarly rich field once the greatest ocean in the world was opened up to exploration in the mid-eighteenth century.

Two individuals - one a scientist and disciple of Cuvier, writing at the beginning of the period; the other a missionary, writing near its end-give us a sense of the obscurity of Pacific Neptunism in the first half of the nineteenth century. François Péron was every inch a product of revolutionary Napoleonism: a self-made polymath from the provinces who talked his way onto the luckless Baudin expedition to Australia in 1802 and became in effect its chief scientist. John Williams, hero and martyr of the London Missionary Society, was every inch Péron's antithesis: the product of the British religious revival that had emerged in response to the Enlightenment the principles of which the Frenchman served, and stolidly, almost painfully, devout, right up to his murder at the hands of the indigenes on a beach at Eromanga in 1839. Thirty years and an immense ideological gulf divided these two travellers in the Pacific, but they possessed essentially the same imaginative restrictions on their capacity to burst what Rudwick calls "the limits of time." As part of his account of the Baudin expedition Péron included a volume of "dissertations on various subjects," including one "On Some Phenomena of the Zoology of the Southern Regions, which can be Applied to the Physical History of the Earth and of the Human Species," the second section of which dealt with "Zoological Observations Calculated to Establish the Ancient Sea-Level on the Summit of the Mountains of Van Diemen's Land, New Holland and Timor." "One of the finest results of modern geological research, and also one of the most uncontestable," he asserted, "is the certainty that the level of the sea was once much higher than it is now." The evidence for this fact was twofold: petrified seashells found on elevated pieces of ground, and "Zoophytes observed at great heights above the present level of the sea; madreporic islands and archipelagoes" (Péron 3: 34). "Either the land has risen or the sea has gone down," as Péron's Pacific predecessor, Bougainville, had said (Péron 3: 45); but Péron could hardly envisage how the former process could have come to pass. "Most of those countless islands scattered through the great equatorial ocean appear to be," he argued, "the work of these feeble zoophytes" (3: 40), but the spectator "has difficulty in conceiving how, by such apparently feeble means, Nature has been able to raise from the bed of the sea those vast mountain 
plateaux which stretch over the surface of the land" (Péron 3: 43). Yet, on the other hand (Péron 3: 44), "everything proclaims the power of zoophytes and the prodigious antiquity of their labours." Volcanos are the only things that make land rise, Péron was sure; but they could not possibly have raised all this coralline rock above the sea - and, besides, they always left evidence of their activity, and none was to be seen in the antipodes. Thus in his "General Results" Péron concluded (3: 47): "We discovered living zoophytes sowing the seas with fresh dangers, multiplying reefs, increasing the size of islands and archipelagoes, cluttering roadsteads and ports and raising up new calcareous mountains everywhere."

For John Williams "modern geological research" would have counted mostly as what he called "prying researches after knowledge." "The great object for which all knowledge should be sought, and for which it ought to be employed," he wrote in his chapter on coral formations:

is to illustrate the wisdom or goodness of the great and beneficent Creator. And if we come to the study of natural phenomena, with minds unchilled by scepticism or infidelity, we shall be led to sublime religious contemplations; and whether we examine the little coral insect of the ocean, or gaze upon the gigantic beast of the forest; whether we study the little glow-worm which twinkles upon the bank, or the celestial luminaries performing their appointed revolutions in majestic silence, amidst the vast expanse of infinity...we shall be led to exclaim: "How manifold, O God, are thy works! in wisdom thou hast made them all." (7)

In a sense, Williams was nearer to the mark than Péron (who thought that coral reefs were built "from the floor of the ocean right up to its surface"; $3: 41$ ). Coral, in his view, needed to find a suitable spot, a suitable platform, and having found it, "innumerable myriads of these wonderful little animals work with incredible diligence until they reach the surface of the water, above which they cannot build." (Williams 8.) Their diligence was worthy of the Victorian seal of approval, but coral could not have built the islands, in Williams' view: they simply did not have the time. According to contemporary scientific estimates of growth, "eighteen thousand years would be required to produce the island visited by Captain Beechy, thirty thousand for the rocks of Rurutu, and fifty to sixty thousand for those of Mangaia; and only that portion of them which appears above water!" (Williams alludes to Frederick William Beechey (1796-1856), who travelled the Pacific from 1826 to 1828.) This "amazing length of time," since it was inconsistent with Biblical history and Bishop Ussher's six-thousand years estimate of the age of the Earth, must be inconsistent with nature; and so, "After all...that I have seen, and thought, and read upon the subject, my impression is, that the islands remain much in the same state as the deluge left them, and that every subsequent alteration has been partial in its character, and exceedingly limited in its extent" (Williams 9-10).

So it was that Péron managed vastly to exaggerate coral activity in the Pacific region, and Williams managed vastly to underestimate it. The first spoke about "prodigious antiquity," but really could account for coral islands only in terms of prodigious dynamism; the second spoke about "incredible diligence," but strictly curtailed the amount of antiquity he would afford it. But in fairness we can see both of them 
striving to account, imaginatively as well as rationally, for the manifestations they witnessed: in particular, coral rock above the surface of the water.

The land-based geologist of the late eighteenth and early nineteenth centuries had immense sources of information available to him: stratigraphy, above all, revealed by erosion, mines, even by canal cuttings (which were shallow, but straight and level); but also volcanic activity - not to mention the fossil record which accompanied the stratigraphic one, and which was dominated by marine animals anyway. By comparison, sea-based geology was to all intents and purposes an impossibility: though not one geologists could ignore. (The fossil record was literally stuffed with ammonite samples, for example; but no living ammonites could be found on earth. Were they extinct? Or simply hiding somewhere in the world's oceans?) "Palaeontologists were agreed," Rudwick points out (Scenes from Deep Time 321-2), that the great majority of fossils were the remains of organisms that had lived in the sea, and wholly underwater at that. Any adequate visual representation of the deep past therefore had to include some way to depict that underwater world. Even the present-day relatives of those organisms could not easily be seen in their natural habitats.... So the problems of picturing a prehuman world were compounded by those of depicting a world that was also nonhuman because it was subaqueous. For artists, the solution to this dilemma was simple, but hardly convincing. Mostly they "portrayed ordinary marine organisms as having been washed up on a shore, in the foreground of a landscape seen unproblematically from a human viewpoint" (Scenes from Deep Time 322), and Rudwick reproduces many post-diluvial pictures of such shorelines - as often as not fringed with coconut palms, as if deep time was inevitably tropical time, or as if the coral island was as primitive as its nineteenthcentury inhabitants. The subaqueous arena was an imaginary one by definition before the snorkel and the aqualung, but this particular part of it - the newly emergent world of tropical zoophytes: shallow, clear, calm, and colourful—was empirically observable, too. "The controversy over coral reefs in the first half of the nineteenth century," D. R. Stoddart writes (213), "illuminates a minor but not insignificant component of the new geology and biology." In purely scientific terms, no doubt this is true; in terms of that interweaving of biology and geology that necessarily involved imaginative input from secular and religious thinkers alike, coral is the marine equivalent of the volcano in bursting of the limits of time. Like the volcano, but in a different medium, the coral reef began to suggest imaginatively, even before it demonstrated empirically, the amount of time the earth had taken writing its own history. (Vesuvius had erupted in $79 \mathrm{AD}$, and its slopes were now covered by earth to certain depths: thus the deposition of soil above volcanic lava could be or become a measure of time. If science discovered how fast coral grew, and could establish some sort of date from which to measure its growth in a particular locality, it could date rock in a similar way.) So it is that Katharine Anderson proposes coral (49) "as a key to Victorian ideas (and anxieties) about marine life and earth's history," themselves "bound up with the view of coral polyps as a liminal form of life, a bridge between organic and inorganic worlds." "As miniature worlds," she goes on (50), coral reefs "were sometimes perceived as fragile or vulnerable, sometimes as centres of generative or transformative energy." These accounts and ideas are clearly among the "constructions" Martin Rudwick spoke of, employing inputs beyond the strictly scientific. "Corals were animals, but they were also islands," as Rebecca Stott writes (64); "They were individuals living in colonies, working together, independent and 
interdependent. They were animals that looked like plants-plants that worked like animals."

These imaginative-cum-empirical constructions of the coralline Pacific have their origin in the work of Johann Reinhold Forster, who accompanied Cook on his second voyage of 1772-1775: surely the most intuitive scientist to travel the southern ocean before Darwin. It was Forster who first made a cardinal distinction (107): "We found low isles, connected by reefs of coral rocks; we met with islands more elevated, some without a reef, and others surrounded by a reef of lithophytes." And it was Forster, too, who first imagined the process by which a sea-washed coral platform might become an island:

The reef, or the first origin of these isles, is formed by the animalcules inhabiting the lithophytes. They raise their habitations within a little of the surface of the sea, which gradually throws shells, weeds, sand, small bits of corals, and other things on the tops of these coral rocks, and at last fairly raises them above water; where the above things continue to be accumulated by the sea, till by a bird, or by the sea, a few seeds of plants, that commonly grow on the sea-shore, are thrown up, and begin to vegetate; and by their annual decay and re-production from seeds, create a little mould, yearly accumulated by the mixture with sand, increasing the dry spot on every side; till another sea happens to carry a coco-nut hither, which preserves its vegetative power a long time in the sea, and therefore will soon begin to grow on this soil, especially as it thrives equally in all kinds of soil; and thus may all these low isles have become covered with the finest coco-nut trees. (108)

Forster's Pacific was both Vulcanist and Neptunist: for him, the low islands grew from coral, the high ones from volcanos. He could not grasp either the nature of their connection in a cycle of subsidence and coral construction, or the vast amount of time required to effect that connection and to allow for the possibility that low islands were only ancient high ones. But in other respects his insight was fundamental.

Navigators travelling the Pacific were convinced that coral was a long time growing. Of such reefs, Charles Claret de Fleurieu wrote in his account of the Marchand circumnavigation of 1790-1792 (2: 324) "that they are the product of centuries; that the work is not finished; that they are made by a gradual increase; but that long stretch of time is necessary for that increase to become apparent." Many such mariners were misled regarding the raising of coral habitations by the immense depths surrounding shallow reefs in the Pacific. Such reefs, the naturalist Jacques Labillardière recorded at Bougainville (152-3), "are built perpendicularly, and quite close to them, no bottom can be found with one hundred fathoms of line. They rise, like so many columns, from the bottom of the sea, and their progressive augmentation daily increases the danger of navigating those parts of the ocean." Here was the origin of those myths we have seen Péron repeat: that coral must make its architectural way from the ocean floor, and that its spread at the surface was rapid. Matthew Flinders, the first explorer to circumnavigate Australia in 1802-1803, also imagined coral starting its work "at the bottom of the ocean," and admired "the care taken to work perpendicularly in the early stages," which marked "a surprising instinct in these diminutive creatures" (2: 115). Otto von Kotzebue travelled the Pacific between 1815 and 1818, but his scientists were in disagreement about such phenomena. The islands, Adelbert von 
Chamisso argued in his "Remarks and Opinions of the Naturalist of the Expedition," "are table mountains, which rise perpendicularly from the depths of the ocean, and near which the lead finds no bottom" (Kotzebue 2: 356). On the contrary, his friend and colleague Friedrich von Eschscholtz pointed out in his chapter, "On the Coral Islands," "Their situation with respect to each other, as they often form rows, their union in several places in large groups, and their total absence in other parts of the same seas, make us conclude, that the corals have founded their buildings on shoals in the sea; or, to speak more correctly, on the tops of mountains lying under water" (Kotzebue 3: 331). This translation of the surface record onto the submarine one- to the effect that islands formed groups, just as mountains did—was a brilliant intuition; and Eschscholtz imaginatively developed Forster's account of island evolution with an injection of historical irony that would be repeated by future coral imaginists:

Entire trunks of trees, which are carried by the rivers from other countries and islands, find here, at length, a resting place, after their long wanderings: with these, come some small animals, such as lizards and insects, as the first inhabitants. Even before the trees for a wood, the real sea-birds nestle here; strayed land-birds take refuge in the bushes; and at a much later period, when the work has long since been completed, man also appears, builds his hut on the fruitful soil formed by the corruption of the leaves of the trees, and calls himself lord and proprietor of this new creation. (Kotzebue 3: 332-3)

By the time Eschscholtz's theory had appeared a pair of naturalists accompanying Louis de Freycinet around the world between 1817 and 1820 had, so to speak, blown it out of the water. Jean René Quoy and Joseph Paul Gaimard "demonstrated for the first time that reef-building corals could only grow in shallow water" (Stoddart 200). Such a report from the field should have put paid to the "up-from-the-abyss" school of thought almost immediately. But there was something about innumerable myriads of wonderful little animals working with incredible diligence until they reached the surface of the water that English writers, in particular, would not willingly let die. There was a sense of purpose in reef building that pious commentators, in particular, found appealing. This was not just a matter of coral insects "raising monuments to their wonderful labours," as Flinders had put it; he also spoke about their "instinctive foresight" in releasing "their infant colonies" to their shelter of their leeward sides (2: 115); and such remarks, of course, pleased and encouraged devout authors on the subject.

Thus in 1828 Granville Penn sought to explain the geological world to children in a set of conversations two children are imagined to have with their very well informed mother. "I think I remember seeing it remarked in some book of voyages," the daughter of the house observes, "that Otaheité, and all the islands of the South Seas, have been raised from the sea by insects; now, I cannot help thinking this, if true, to be very extraordinary" - such insects, Christina adds, "must either be very large or very numerous" (Penn 147). In her explanation her mother cites Cook, Forster, and Flinders, and points out, inter alia, that coral atolls are built "with their backs to the sea, as if the coral animalcules were aware of the properties of the arch." Such a thing "cannot be explained otherwise than by the operation of intelligence and design" (Penn 152, 157). In the same year, in the third edition of his Introduction to Geology Robert Bakewell acknowledged Quoy and Gaimard at one end of his book while at the other offering the old account of islands and reefs being "raised from the vast 
depths in the course of a few years" (334): a process which "is still going on rapidly and extensively in the Southern Ocean" (86). A year later Andrew Ure theorized that "coral islands offer proofs of the elevation of submarine strata by expansive forces, acting at periods probably not very remote from our own times, and therefore they are well calculated to throw light on the more ancient and obscure phenomenon of the deluge." "Not very remote" is not very precise, true; but the main thing is that the Biblical deluge is safely established as an event of far greater obscurity and antiquity than modern geological elevations, onto which only some light might be thrown by modern discoveries. "It is highly probable," for example, "that the numerous volcanic chimnies which... rise through the vast Pacific, are remnants of the general convulsion which raged at the deluge, ending in the submersion of some primeval continent, corresponding probably in area to the surface of that ocean" (Ure 466-7). Again: it is easy to smile at this; but "volcanic chimnies" is by no means the worst expression to use of those tectonic vents that are the sources of all the non-continental islands of the Pacific, high and low.

In 1829 Andrew Ure imagined a disappearing Pacific continent. Two years later John MacCullough imagined a rising one. By common consent, he wrote, it was understood that coral atolls and islets were "crowding the whole of the sea, under a rapid increase." Was it not likely, therefore, that they were "destined to become the seats of vegetation, and the habitations of man, and perhaps, at length, to form a continent in the Pacific Ocean" (MacCullough 338, 339)? Like Penn's, MacCullough's vision was one of intelligent design: that so many reefs were roughly circular he felt to be an instance of "singular ingenuity, as it respects the form and character of the future island." As islands rose, furthermore, the seawater trapped in their atolls would surely become diluted by rain, until it ceased to be salt at all: thus opening the way for animal life. Was this not a case of "foresight and contrivance" (MacCullough 341-2)? Even as late as 1838, Gideon Mantell was mixing truth with legend in these respects. "It is," he rightly said (472) "within the tropics, in a zone of more than 60 degrees expansion, that these beings, scarcely visible to the naked eye, exercise their empire in a medium whose temperature knows no change." But he also indulged himself Jules Verne-style (487-8): "From the depths of the ocean they elevate those immense reefs that may hereafter form a communication between the inhabitants of the temperate zones." (In short: "a new continent may spring up where fabled Atalantis once flourished.") In 1845 Philip Henry Gosse-perhaps the most famous intellectual fatality in the evolution wars - was still discussing "the Divine care" God gave "the little creatures which rear these solid structures," in that coral atolls displayed openings just sufficient to let seawater and native canoes come and go, but "of insufficient width and depth to permit the free ingress of large ships" (252). Intelligent design, indeed!

Twenty years later yet, Louis Agassiz had set himself free from Archbishop Ussher's cosmogony, but still clung to the idea of purposeful theodicy. Like coal, coral—-who have worked so busily during the long centuries, that there are extensive countries, mountain-chains, islands, and long lines of coast consisting solely of their remains"humiliated our sense of time (149). "Leaving aside... all historical chronology, how far back can we trace our own geological period, and the Species belonging to it? By what means can we determine its duration? Within what limits, by what standard, may it be measured? Shall hundreds, or thousands, or hundreds of thousands, or millions of years be the unit from which we start?" (151.) "In these seventy thousand years," 
for example, "has there been any change in the Corals living in the Gulf of Mexico? I answer most emphatically, No" (Agassiz 190). So Agassiz was prepared to give corals, in abundance, the time John Williams denied them. But the ubiquity and stability of coral species only made a pious conclusion more inevitable (198): that "this recurrence of the same thought in the history of animals of the same Type" demonstrates that "from whatever side we consider them, their creation and existence seem to be guided by one Mind." From little things, big things grow, and "these little beings" had a primary role to play in Creation (200): "to make a masonry solid, compact, time-defying, such a masonry as was needed by the great Architect, who meant that these smallest creatures of His hand should help to build His islands and His continents." This was an imaginative pattern that many found simply too attractive, and too harmonious, to deny.

But Agassiz, for all his piety, had begun to burst the limits of time, and speculate in terms of millions of years. That was the most important lesson Charles Lyell, James Dana, and (of course) Charles Darwin drew from coral. "When we admit the increase of coral limestone to be slow," Lyell pointed out (287), "we are merely speaking with relation to periods of human observation" - and limitations of human imagination, it may be. "Natural chronometers" (288), with their roots in deep time, would be needed to grasp the prodigious antiquity at which Péron had only waved his hand. (By 1837, and with the benefit of Darwin's research, Lyell could see that "Coral islands are the last efforts of drowning continents to lift their heads above water" Katharine Murray Lyell 2: 12). Dana estimated coral growth at a thousand years per five feet (253); it was a scale of this temporal magnitude that led him to conclude (318): "In this direction... we find the grandest teaching of coral formations." Darwin treated the antiquity and the rate of growth of coral reefs with the peculiarly Olympian grave insouciance that marks his entire project. For him such reefs, "young" or "old" (whatever those words might mean), belonged only to "the present geological æra" (which means that as natural chronometers they themselves were only recent innovations). Accordingly, coralline growth is never slow, "when referred either to the standard of the average oscillations of level in the earth's crust, or to the more precise but less important one of a cycle of years" (Darwin, Structure and Distribution 79).

It was the founding father of systematic geology, James Hutton, who said (qtd in Toulmin and Goodfield 156): "time is not made to flow in vain; nor does there ever appear the exertion superfluous to power, or the manifestation of design, not calculated in wisdom to effect some general end." Hutton's is, if one may say so, a sort of Whiggish interpretation of geohistory, that the nineteenth century began to replace with a sometimes scarcely renovated version of something far older: a cyclical vision of contending forces, neither achieving final victory over the other. "Whatever destroying tendencies, then, exist on earth," William Knight wrote in 1818 (in a discussion of the "formation of new land by coral worms"), "these renovating powers compensate for them.... No marks of a degradation acting through a prolonged series of ages are exposed to our observation, without being met by constant renewal. The one arises out of the other." And "one great and good Being" was the orchestrator of this irreducible algorithm (Knight 258; my italics). For Agassiz, too (176), "destruction and construction go hand in hand, and the materials broken or worn away from one part of the Reef help to build it up elsewhere." Such a pattern was one of those "intellectual links in Creation, which give such coherence and consistency to the 
whole, and make it intelligible to man" (Agassiz 192). This was a theodicy Darwin himself (at least in his early days, on the Beagle) was prepared to walk towards, in his infinitely methodical but also visionary way:

These coral islands stand, and are victorious: for here another power, as antagonist to the former, takes part in the contest. The organic forces separate the atoms of carbonate of lime one by one from the foaming breakers, and unite them into a symmetrical structure. Let the hurricane tear up its thousand huge fragments; yet what will this tell against the accumulated labour of myriads of architects at work night and day, month after month? Thus do we see the soft and gelatinous body of a polypus, through the agency of vital laws, conquering the great mechanical power of the waves of an ocean, which neither the art of man, nor the inanimate works of nature could successfully resist. (Darwin, Voyage 338)

Not everybody could see atoms of calcium carbonate being woven and unwoven by coral polyps and the action of the waves. But, as usual, Darwin built not only on the knowledge but also the imaginings of his predecessors - pious as well as secular.

\section{Works Cited}

Agassiz, Louis. Methods of Study of Natural History. Boston: Ticknor and Fields, 1863. Print.

Anderson, Katharine. “Coral Jewellery.” Victorian Review 34: 1 (2008): 47-53. Print.

Bakewell, Robert. An Introduction to Geology: Comprising the Elements of the Science in its Present Advanced State. New Haven: No Pub., 1829. Print.

Dana, James D. Corals and Coral Islands. London: Sampson Low, Marston, Low, and Searle, 1872. Print.

Darwin, Charles. The Structure and Distribution of Coral Reefs. London: Smith, Elder, 1842. Print.

--- The Voyage of the Beagle. Ed. Janet Browne and Michael Neve. London: Penguin, 1989. Print.

Fleurieu, Charles Pierre Claret de. Voyage autour du monde, pendant les années 1790, 1791, et 1792, par Etienne Marchand. Paris, 1798-1800. Print.

Flinders, Matthew. Voyage to Terra Australis. London: G. and W. Nichol, 1814. Print.

Forster, Johann Reinhold. Observations Made During a Voyage Round the World. Ed. Nicholas Thomas, Harriet Guest, and Michael Dettelbach. Honolulu: University of Hawai'i Press, 1996. Print. 
Gosse, Philip Henry. The Ocean. London: Society for the Propagation of Christian Knowledge, 1845. Print.

Knight, William. Facts and Observations towards Forming a New Theory of the Earth. London: Longman, Rees, Orme, Brown, and Green, 1818. Print.

Kotzebue, Otto von. A Voyage into the South Sea and Beerings Straits. London: Longman, Hurst, Rees, Orme, and Brown, 1821. Print.

Labillardiére, Jacques. Voyage in Search of La Pérouse, Performed by Order of the Constituent Assembly, During the Years 1791, 1792, 1793, and 1794. London: John Stockdale, 1800. Print.

Lyell, Charles. Principles of Geology. Vol. 2. London: John Murray, 1832. Print.

Lyell, Katharine Murray. Ed. Life, Letters and Journals of Sir Charles Lyell. London: John Murray, 1881. Print.

MacCullough, John. A System of Geology, with a Theory of the Earth, and an Explanation of its Connexion, with the Sacred Records. London: Longman, Rees, Orme, Brown, and Green, 1831. Print.

Mantell, Gideon. The Wonders of Geology. London: Relfe and Fletcher, 1838. Print.

Penn, Granville, Conversations on Geology. London: Samuel Maunder, 1828. Print.

Péron, François. Voyage of Discovery to the Southern Lands. 2nd ed. Trans. Christin Cornell. Adelaide: Friends of the State Library of South Australia, 2007. Print.

Rudwick, Martin J. S. Scenes from Deep Time: Pictorial Representations of the Prehistoric World. Chicago: University of Chicago Press, 1992. Print.

--- Bursting the Limits of Time: The Reconstruction of Geohistory in the Age of Revolution. Chicago: University of Chicago Press, 2005. Print.

Stoddart. D. R. "Darwin, Lyell, and the Geologial Significance of Coral Reefs." British Journal of the History of Science 9: 2 (1976): 199-218. Print.

Stott, Rebecca. Darwin and the Barnacle. London: Faber and Faber, 2003). Print.

Toulmin, Stephen, and June Goodfield. The Discovery of Time. London: Hutchinson, 1965. Print.

Ure, Andrew. A New System of Geology, in which the Great Revolutions of the Earth and Animated Nature, Are Reconciled at Once to Modern Science and Sacred History. London: Longman, Rees, Orme, Brown, and Green, 1829. Print.

Williams, John. A Narrative of Missionary Enterprises in the South Sea Islands. London: John Snow, 1840. Print. 